Mater. Res. Soc. Symp. Proc. Vol. 1475 @ 2012 Materials Research Society

DOI: 10.1557/opl.2012.590

\title{
Surface Electrochemistry of Uranium Dioxide in Acidic Hydrogen Peroxide Solutions
}

\author{
Mayuri Razdan ${ }^{1}$, David Hall ${ }^{2}$ and David W. Shoesmith ${ }^{1}$ \\ ${ }^{1}$ Department of Chemistry, University of Western Ontario, London, ON N6A 5B7, Canada \\ ${ }^{2}$ Department of Chemistry, University of Ottawa, Ottawa, ON K1N 6N5, Canada
}

\begin{abstract}
The electrochemical reduction of $\mathrm{H}_{2} \mathrm{O}_{2}$ on SIMFUEL was investigated over the $\mathrm{pH}$ range 1 to 4 . The mechanism at $\mathrm{pH} 4$ is known to occur on $\mathrm{U}^{\mathrm{V}}$ species incorporated into a surface layer of $\mathrm{U}^{\mathrm{IV}}{ }_{1-2 \mathrm{x}} \mathrm{U}^{\mathrm{V}}{ }_{2 \mathrm{x}} \mathrm{O}_{2+\mathrm{x}}$. However, below $\mathrm{pH} 3$, reduction occurs on an adsorbed $\mathrm{U}^{\mathrm{V}} \mathrm{O}_{2}(\mathrm{OH})$ state which is unstable and oxidizes to insulating $\mathrm{U}^{\mathrm{VI}}$ before dissolving as $\mathrm{UO}_{2}{ }^{2+}$. Both schemes are observed at intermediate $\mathrm{pH}$ 's. The presence of both low and high acidic regions at the electrode surface is determined by the combination of peroxide concentration, bulk $\mathrm{pH}$ and the surface diffusion conditions.
\end{abstract}

\section{INTRODUCTION}

Long term management of spent nuclear fuel requires the study of its corrosion and dissolution under permanent waste disposal conditions [1], when the spent fuel would be enclosed in corrosion resistant copper containers and buried in the granitic rock of the Canadian Shield surrounded by compacted bentonite clay $[2,3]$. These metallic containers are designed to survive until radiation fields become insignificant. However, if failure occurs, water radiolysis will produce hydrogen peroxide, which will drive fuel corrosion and a mixed potential model has been developed to predict the corrosion behaviour [4].

The production of $\mathrm{H}_{2} \mathrm{O}_{2}$ will complicate surface redox conditions since it can also decompose at the fuel surface to produce $\mathrm{H}_{2} \mathrm{O}$ and $\mathrm{O}_{2}$ [5-8]. Electrochemical studies have shown that peroxide reduction occurs in two steps: the creation of $\mathrm{U}(\mathrm{V})$ by chemically oxidizing the $\mathrm{UO}_{2}$ surface (1) followed by the electrochemical regeneration of $\mathrm{U}(\mathrm{IV})$ (2)

$$
\begin{aligned}
& 2 \mathrm{U}^{\mathrm{IV}}+\mathrm{H}_{2} \mathrm{O}_{2} \rightarrow 2 \mathrm{U}^{\mathrm{V}}+2 \mathrm{OH}^{-} \\
& 2 \mathrm{U}^{\mathrm{V}}+2 \mathrm{e}^{-} \rightarrow 2 \mathrm{U}^{\mathrm{IV}}
\end{aligned}
$$

Under natural corrosion conditions dissolution occurs as $\mathrm{UO}_{2}{ }^{2+}$, followed by deposition of $\mathrm{UO}_{3} \mathrm{yH}_{2} \mathrm{O}$, which suppresses further fuel oxidation by blocking surface sites. In neutral to slightly alkaline ground water the overall corrosion process becomes limited by the slow release rate of $\mathrm{U}^{\mathrm{VI}}$ into solution [9]. However, the presence of pores or inhomogeneities (surface flaws, sintering porosity) in the corrosion product and the fuel could lead to local acidification at these sites, introducing a $\mathrm{pH}$ gradient and a chemical driving force to retain porosity and sustain film growth [9-11]. In acidic solutions $(\mathrm{pH}<6)$ corrosion products would become unstable and redissolve, leading to increased dissolution rates [12]. Thus, though unlikely, corrosion of fuel in acidified peroxide conditions could constitute a rapid release pathway for radionuclides.

In this paper, we report a study of the influence of acidic conditions on $\mathrm{H}_{2} \mathrm{O}_{2}$ reduction on $\mathrm{UO}_{2}$, in particular the effects of peroxide concentration and surface diffusion conditions. 


\section{EXPERIMENTAL}

Experiments were performed on 1.5 at $\%$ SIMFUEL, an unirradiated analogue of spent nuclear fuel fabricated by Atomic Energy of Canada (Chalk River, Canada) [13]. The electrodes were $\sim 2 \mathrm{~mm}$ thick and $1.2 \mathrm{~cm}$ in diameter and were prepared as described [14]. A standard threeelectrode, three-compartment cell was used for all experiments. The working electrode was screwed on to the shaft of an analytical rotator (Pine Instruments) allowing the electrode rotation to be varied from 5 to $33 \mathrm{~Hz}$. The counter electrode was a Pt sheet of surface area $\sim 6 \mathrm{~cm}^{2}$, spot welded to a Pt wire. A Solartron model 1287 potentiostat was used to record the current as a function of applied potential. The current interrupt method was used to counterbalance the potential drop due to electrode resistance. A saturated calomel electrode (SCE) was used as the reference electrode.

Experiments were performed in $0.1 \mathrm{~mol} \mathrm{~L}^{-1} \mathrm{NaCl}$ (Caledon, >99\%) using deionized water purified by a Millipore milli Q plus $(\rho=18.2 \mathrm{M} \Omega \mathrm{cm})$. The solutions were purged with Ar gas (Praxair) before each experiment. The concentration of $\mathrm{H}_{2} \mathrm{O}_{2}$ (Fisher Scientific, 3\%) was determined by ultra-violet/visible spectrophotometry.

$\mathrm{X}$-ray photoelectron spectroscopy was used to analyze the electrode surface by using monochromatic $\mathrm{AlK}_{\alpha}$-radiation $(h v=1486.6 \mathrm{eV})$. The $\mathrm{C}(1 \mathrm{~s})$ line at $285 \mathrm{eV}$, present due to adventitious carbon on the electrode surface, was used, when necessary, to correct for surface charging. The uranium $4 \mathrm{f}$ spectrum was deconvoluted into $\mathrm{U}^{\mathrm{IV}}, \mathrm{U}^{\mathrm{V}}, \mathrm{U}^{\mathrm{VI}}$ contributions arising from $U \mathrm{Uf}_{7 / 2}, 4 \mathrm{f}_{5 / 2}$ and satellite peaks. The satellite structures and the valence band region were used to check the validity of the fit.

\section{RESULTS AND DISCUSSION}

Figure 1 shows $\mathrm{CVs}$ recorded in $\mathrm{H}_{2} \mathrm{O}_{2}$ solutions at various $\mathrm{pH}$ values in the range 1 to 3 . The individual reduction processes observed are consistent with previous observations. The current in region 1 is due to $\mathrm{H}^{+}$reduction enhanced on $\varepsilon$-particles in the surface of the SIMFUEL, and, as expected, the current density increases as $\mathrm{pH}$ decreases $[15,16]$. At $\mathrm{pH} 3.00$, the current in region 2 is attributed to $\mathrm{H}_{2} \mathrm{O}_{2}$ reduction on a catalytic $\left(\mathrm{U}^{\mathrm{IV}}{ }_{1-2 \mathrm{x}} \mathrm{U}_{2 \mathrm{x}}^{\mathrm{V}} \mathrm{O}_{2+\mathrm{x}}\right)$ layer in which $\mathrm{O}^{2-}$ anions have been injected into the $\mathrm{UO}_{2}$ lattice and $\mathrm{U}^{\mathrm{V}}$ species created by reaction 1 [17]. This process has been thoroughly investigated $[11,17,18]$ and the $\mathrm{U}^{\mathrm{IV}}{ }_{1-2 \mathrm{x}} \mathrm{U}_{2 \mathrm{x}} \mathrm{O}_{2+\mathrm{x}}$ layer is stabilized by $\mathrm{OH}^{-}$anions, but becomes unstable at low $\mathrm{pH}(<5)[19]$. Its existence in more acidic solutions is a result of the generation of a higher $\mathrm{pH}$ at the electrode surface by reaction 2 [11]. Rotating disk electrode studies show that $\mathrm{H}_{2} \mathrm{O}_{2}$ reduction on this surface to be diffusion controlled at low potentials $(\leq-0.8 \mathrm{~V}$ vs. SCE) [20].

At $\mathrm{pH} \leq 2.60$, a separate $\mathrm{H}_{2} \mathrm{O}_{2}$ reduction pathway is observed (region 3, Figure 1), and attributed to previously observed $\mathrm{H}_{2} \mathrm{O}_{2}$ reduction catalyzed by an adsorbed $\mathrm{U}^{\mathrm{V}}$-containing surface species [11]. Here, an alternative interpretation is suggested: a two-step process in which $\mathrm{H}_{2} \mathrm{O}_{2}$ reduction is coupled to $\mathrm{UO}_{2}$ oxidation to form a $\mathrm{U}^{\mathrm{V}}$ species coordinated on the $\mathrm{UO}_{2}$ surface by the $\mathrm{OH}^{-}$produced,

$$
2 \mathrm{UO}_{2}+\mathrm{H}_{2} \mathrm{O}_{2} \rightarrow 2 \mathrm{U}^{\mathrm{V}} \mathrm{O}_{2}(\mathrm{OH})
$$


This intermediate is then reduced electrochemically, leaving the original $\mathrm{UO}_{2}$ unaltered and generating hydroxide at the electrode surface,

$$
2 \mathrm{U}^{\mathrm{V}} \mathrm{O}_{2}(\mathrm{OH})+2 \mathrm{e}^{-} \rightarrow \mathrm{UO}_{2}+2 \mathrm{OH}^{-}
$$

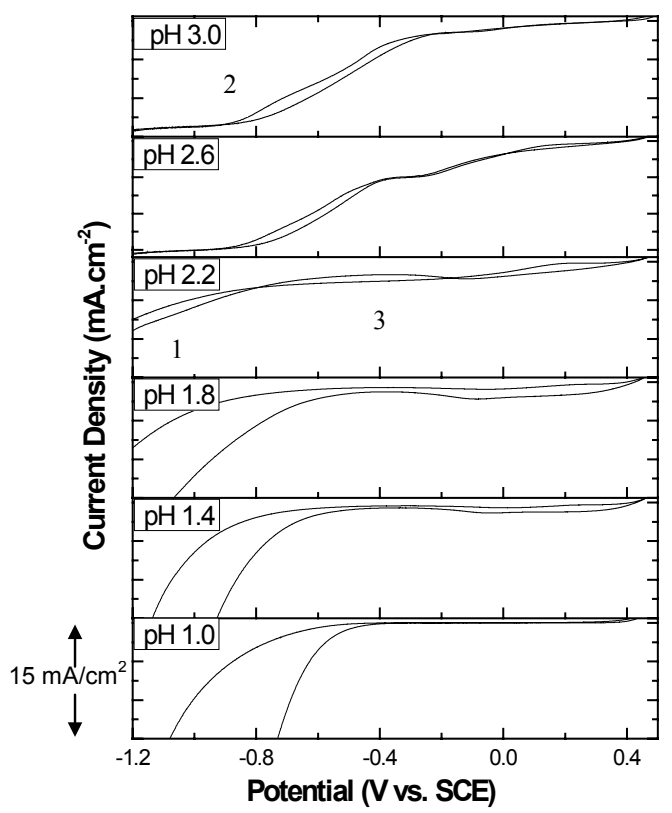

Figure 1. Cyclic voltammograms recorded on 1.5 at.\% SIMFUEL at $10 \mathrm{mV} \mathrm{s}^{-1}$ at an electrode rotation rate of $16.7 \mathrm{~Hz}$ in $0.1 \mathrm{~mol} \mathrm{~L}^{-1} \mathrm{NaCl}$ containing $5 \times 10^{-3} \mathrm{~mol} \mathrm{~L}^{-1} \mathrm{H}_{2} \mathrm{O}_{2}$ at different $\mathrm{pH}$ values. The scans are offset by $15 \mathrm{~mA} \mathrm{~cm}^{-2}$.

Under less acidic conditions, reaction 3 leads, instead, to irreversible surface oxidation by anion incorporation to produce the $\mathrm{U}^{\mathrm{IV}}{ }_{1-2 \mathrm{x}} \mathrm{U}_{2 \mathrm{x}}^{\mathrm{V}} \mathrm{O}_{2+\mathrm{x}}$ layer and generate protons at the electrode surface. Since it is this latter layer which is catalytic for $\mathrm{H}_{2} \mathrm{O}_{2}$ reduction, its absence in acidic solutions leads to a decrease in $\mathrm{H}_{2} \mathrm{O}_{2}$ reduction current.

At $\mathrm{pH} 2.60$, both reduction processes (region 2 and 3 ) are observed, suggesting the presence of chemically non-equivalent regions on the electrode surface; i.e., regions of low and high acidity possibly related to surface roughness.

Figure 2 shows $\mathrm{CVs}$ recorded at $\mathrm{pH}=2.6$. In the absence of $\mathrm{H}_{2} \mathrm{O}_{2}$ (labelled background) the current for proton reduction is small. At low $\left[\mathrm{H}_{2} \mathrm{O}_{2}\right]$ only the current associated with region 3 is observed, while at the higher concentration current in both regions 2 and 3 is observed. This behavior confirms that $\mathrm{H}_{2} \mathrm{O}_{2}$ reduction stabilizes the $\mathrm{U}^{\mathrm{IV}}{ }_{1-2 \mathrm{x}} \mathrm{U}_{2 \mathrm{x}} \mathrm{O}_{2+\mathrm{x}}$ layer when present at a sufficient concentration to cause a significant increase in surface $\mathrm{pH}$. 


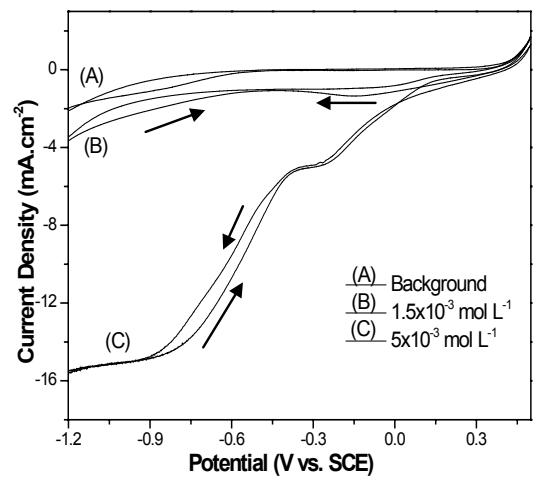

Figure 2. Cyclic voltammograms recorded on 1.5 at.\% SIMFUEL at $10 \mathrm{mV} \mathrm{s}^{-1}$ at an electrode rotation rate of $16.7 \mathrm{~Hz}$ in $0.1 \mathrm{~mol} \mathrm{~L}^{-1} \mathrm{NaCl}$ at $\mathrm{pH} 2.6$ containing $\left[\mathrm{H}_{2} \mathrm{O}_{2}\right]$ : (A) $0 \mathrm{~mol} \mathrm{~L}^{-1}$; (B) 1.5 $\times 10^{-3} \mathrm{~mol} \mathrm{~L}^{-1}$ and (C) $5 \times 10^{-3} \mathrm{~mol} \mathrm{~L}^{-1}$. The arrows indicate scan direction.

Figure 3 shows background-corrected CVs recorded at different $\mathrm{pHs}$ and $\left[\mathrm{H}_{2} \mathrm{O}_{2}\right]$ as a function of electrode rotation rate. At $\mathrm{pH} 4.0$ and $\left[\mathrm{H}_{2} \mathrm{O}_{2}\right]=6 \times 10^{-4} \mathrm{~mol} \mathrm{~L}^{-1}$, reduction occurs at a rate approaching the diffusion-controlled limit on a $\mathrm{U}^{\mathrm{IV}}{ }_{1-2 \mathrm{x}} \mathrm{U}_{2 \mathrm{x}}^{\mathrm{V}} \mathrm{O}_{2+\mathrm{x}}$ surface. At $\mathrm{pH}=3.0$ and $\left[\mathrm{H}_{2} \mathrm{O}_{2}\right]=8 \times 10^{-4} \mathrm{~mol} \mathrm{~L}^{-1}, \mathrm{OH}^{-}$formation by $\mathrm{H}_{2} \mathrm{O}_{2}$ reduction is too low to disturb the local $\mathrm{pH}$ sufficiently to cause formation of this layer and the reduction of $\mathrm{H}_{2} \mathrm{O}_{2}$ is inhibited and proceeds uncatalyzed, reactions 3 and 4 . The current increase at very negative potentials can be attributed to $\mathrm{H}_{2} \mathrm{O}_{2}$ reduction on a catalytic layer stabilized by $\mathrm{OH}^{-}$produced from both $\mathrm{H}_{2} \mathrm{O}_{2}$ and $\mathrm{H}^{+}$ reduction.

At an intermediate $\mathrm{pH}$, when $\left[\mathrm{H}^{+}\right]$and $\left[\mathrm{H}_{2} \mathrm{O}_{2}\right]$ are similar, more subtle behavior is observed. On the forward scan $\mathrm{H}^{+}$and $\mathrm{H}_{2} \mathrm{O}_{2}$ reduction produce $\mathrm{OH}^{-}$at the electrode surface leading to the formation of the catalytic layer and diffusion-controlled $\mathrm{H}_{2} \mathrm{O}_{2}$ reduction. At more positive potentials, the rate of $\mathrm{OH}^{-}$production decreases, acidic conditions are reestablished, and the catalytic layer will be destabilized and reaction 3 will lead to the formation of $\mathrm{U}^{\mathrm{V}} \mathrm{O}_{2}(\mathrm{OH})$ as indicated by the kink in the current in the forward scan, Figure 3c. This species is unstable and either further oxidized to soluble $\mathrm{U}^{\mathrm{VI}} \mathrm{O}_{2}{ }^{2+}$ at more positive potentials or electrochemically reduced via reaction 4.

On the reverse scan the instability of this chemically-formed (reaction 3)/ electrochemically-destroyed surface prevents significant $\mathrm{H}_{2} \mathrm{O}_{2}$ reduction. However, for a sufficiently negative potential when the rate of electrochemical reduction of $\mathrm{U}^{\mathrm{V}} \mathrm{O}_{2}(\mathrm{OH})$ will be considerably higher than its rate of chemical formation and the direct surface reduction of $\mathrm{H}_{2} \mathrm{O}_{2}$ becomes possible, then the increased surface $\mathrm{pH}$ will allow the catalytic surface layer to reform. Once this layer is formed, the $\mathrm{H}_{2} \mathrm{O}_{2}$ reduction current increases to the diffusion-controlled limit, Figures 3(c) and 3(d).

This transition on the reverse scan is very sensitive to the surface state, Figures $3(\mathrm{c})$ and $3(d)$, since reestablishment of the diffusion-limited current is very dependent on electrode rotation rate. This is particularly clear in Figure 3 (d) since the $\left[\mathrm{H}_{2} \mathrm{O}_{2}\right]$ is lower than in the 
experiment shown in Figure 3(c) and the build up of $\mathrm{OH}^{-}$at the electrode surface is neutralized by the increased proton flux as the electrode rotation rate increases.
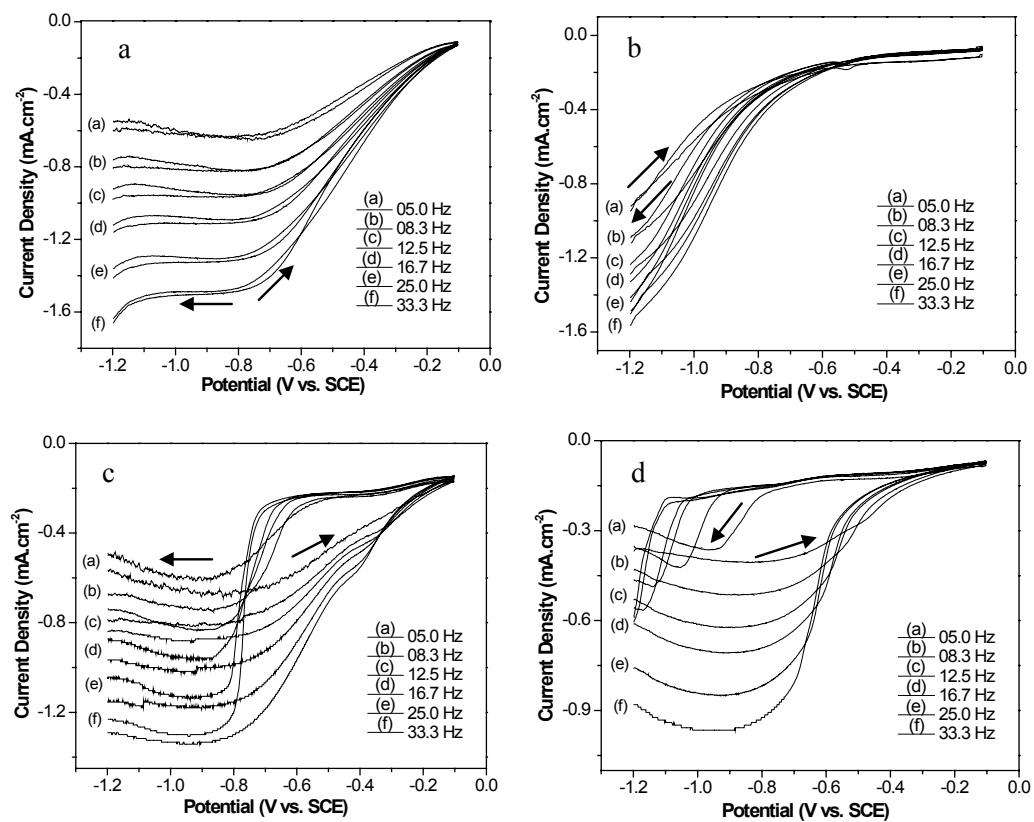

Figure 3. Cyclic voltammograms recorded on a 1.5 at. $\%$ SIMFUEL RDE at $10 \mathrm{mV} \mathrm{s}^{-1}$ in 0.1 $\mathrm{mol} \mathrm{L}-1 \mathrm{NaCl}$ at $\mathrm{pH}$ (a) $4.00,\left[\mathrm{H}_{2} \mathrm{O}_{2}\right]=6 \times 10^{-4} \mathrm{~mol} \mathrm{~L}^{-1}$; (b) $3.0,\left[\mathrm{H}_{2} \mathrm{O}_{2}\right]=8 \times 10^{-4} \mathrm{~mol} \mathrm{~L}^{-1}$; (c) $\mathrm{pH}$ $3.5,\left[\mathrm{H}_{2} \mathrm{O}_{2}\right]=7 \times 10^{-4} \mathrm{~mol} \mathrm{~L}^{-1}$ and (d) $\mathrm{pH} 3.5,\left[\mathrm{H}_{2} \mathrm{O}_{2}\right]=4 \times 10^{-4} \mathrm{~mol} \mathrm{~L}^{-1}$

XPS measurements on electrodes potentiostatically oxidized $(-0.2 \mathrm{~V})$ in $\mathrm{pH} 3.5$ solutions with and without $\mathrm{H}_{2} \mathrm{O}_{2}$ confirms that the coverage of the electrode surface by $\mathrm{U}^{\mathrm{V}}$ is increased when peroxide is present.

\section{CONCLUSIONS}

The mechanism of $\mathrm{H}_{2} \mathrm{O}_{2}$ reduction on SIMFUEL was found to be dependent on $\left[\mathrm{H}_{2} \mathrm{O}_{2}\right]$, electrode rotation rate, and the bulk $\mathrm{pH}(1$ to 4$)$. At lower $\mathrm{pH}$ values in the presence of peroxide, reduction currents are suppressed indicating the formation of the surface adsorbed species $\mathrm{U}^{\mathrm{V}} \mathrm{O}_{2}(\mathrm{OH})$ which is unstable and electrochemically reduces. At higher $\mathrm{pH}$ values for the same $\left[\mathrm{H}_{2} \mathrm{O}_{2}\right]$, reduction currents rise to the diffusion-controlled limit on a $\mathrm{U}^{\mathrm{IV}}{ }_{1-2 \mathrm{x}} \mathrm{U}^{\mathrm{V}}{ }_{2 \mathrm{x}} \mathrm{O}_{2+\mathrm{x}}$ catalytic surface stabilized by $\mathrm{OH}^{-}$anions. For intermediate $\mathrm{pH}$ values, regions of low and high $\mathrm{pH}$ occur on the electrode surface. However, whether or not peroxide reduction approaches the diffusion controlled limit on a $\mathrm{U}^{\mathrm{IV}}{ }_{1-2 \mathrm{x}} \mathrm{U}_{2 \mathrm{x}}^{\mathrm{V}} \mathrm{O}_{2+\mathrm{x}}$ catalytic surface depends on its concentration and the bulk 
solution $\mathrm{pH}$. For $\left[\mathrm{H}_{2} \mathrm{O}_{2}\right] \geq\left[\mathrm{H}^{+}\right]$, peroxide reduction produces $\mathrm{OH}^{-}$at the electrode surface and stabilizes the catalytic $\mathrm{U}^{\mathrm{IV}}{ }_{1-2 \mathrm{x}} \mathrm{U}_{2 \mathrm{x}} \mathrm{O}_{2+\mathrm{x}}$ and the diffusion limit is achieved. However, at lower $\mathrm{pH}$ values (compared to $\left[\mathrm{H}_{2} \mathrm{O}_{2}\right]$ ) the production of $\mathrm{OH}^{-}$at the electrode surface is insufficient to stabilize the catalytic layer and the $\mathrm{H}_{2} \mathrm{O}_{2}$ reduction current is suppressed.

\section{ACKNOWLEDGMENTS}

This research was funded under the Industrial Research Chair agreement between NSERC and Nuclear Waste Management Organization (NWMO), Toronto, Canada. Surface Science Western (UWO) is acknowledged for use of their X-ray photoelectron spectrometer and Dr. J. C. Wren for the use of her UV/VIS spectrophotometer.

\section{REFERENCES}

1 Nuclear Waste Management Organization (NWMO), Choosing a way forward: the future management of Canada's used nuclear fuel. November, 2005. (www.nwmo.ca).

2 J. McMurry, D.A. Dixon, J.D. Garroni, B.M. Ikeda, S. Stroes-Gascoyne, P. Baumgartner, and T.W. Melnyk, Evolution of a Canadian deep geologic repository: Base scenario. Ontario Power Generation report: 06819-REP-01200-10092-R00 (2003).

3 F. King and M. Kolar, The copper container corrosion model used in AECL's second case study. Ontario Power Generation report: 06819-REP-01200-10041-R00, (2000).

4 D. W. Shoesmith, M. Kolar and F. King, Corrosion 59, 802 (2003).

5 M. Amme, Radiochim. Acta 90, 399 (2002).

6 M. Amme, B. Renker, B. Schmid, M. P. Feth, H. Bertagnolli, and W. Dobelin, J. Nucl. Mater. 306, 202 (2002).

7 P. Diaz-Arocas, J. Quinones, C. Maffiotte, J. Serrano, J. Garcia, J. R. Almazan, and J. Esteban, Mater Res. Soc. Symp. Proc. 353, 641 (1995).

8 J. B. Hiskey, Inst. Min. Metall. Trans. Sect. C, 89, C145 (1980).

9 J. C. Wren, D. W. Shoesmith and S. Sunder, J. Electrochem. Soc. 152, B470 (2005).

10 D. W. Shoesmith, J. J. Noël, F. Garisto, Mater. Res. Soc. Symp. Proc. 824, 81 (2004).

11 P. G. Keech, J. J. Noel, and D. W. Shoesmith, Electrochim. Acta 53, 5675 (2008).

12 I. Grenthe, J. Fuger, R. J. Konings, R. J. Lemire, A. B. Muller, C. Nguyen-Trung, and H. Wanner, in Chemical Thermodynamics Vol 1, edited by H. Wanner and I. Forest, (North Holland, Amsterdam, 1992).

13 P. G. Lucuta, R. A. Verrall, H. Matzke, and B. J. Palmer, J. Nuc. Mater. 178, 48 (1991).

14 B. G. Santos, H. W. Nesbitt, J. J. Noel, and D. W. Shoesmith, Electrochim. Acta 49, 1863 (2004).

15 D. W. Shoesmith, J. Nucl. Mater. 282, 1 (2000).

16 D. W. Shoesmith, S. Sunder, and W. H. Hocking, in Electrochemistry of novel materials Vol 297, edited by J. Lipkowski and P. N. Ross, (VCH, New York, 1994), chapter 6.

17 J. S. Goldik, H. W. Nesbitt, J. J. Noel, and D. W. Shoesmith, Electrochim. Acta 49, 1699 (2004).

18 J. S. Goldik, D. W. Shoesmith, and J. J. Noel, J. Electroanal. Chem. 582, 241 (2005).

19 R. J. Lemire and J. Paquette, Nuc. Sci. Eng. 79, 23 (1981).

20 J. S. Goldik, J. J. Noel, and D. W. Shoesmith, J. Electrochem. Soc. 153, E151 (2006). 